\title{
Optimization of Polyethylene Glycol-Mediated Transformation of the Pepper Anthracnose Pathogen Colletotrichum scovillei to Develop an Applied Genomics Approach
}

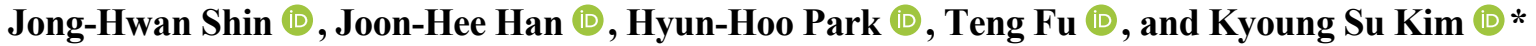 \\ Division of Bio-Resource Sciences and BioHerb Research Institute, Kangwon National University, Chuncheon 24341, \\ Korea
}

(Received on June 22, 2019; Accepted on August 30, 2019)

Colletotrichum acutatum is a species complex responsible for anthracnose disease in a wide range of host plants. Strain $C$. acutatum KC05, which was previously isolated from an infected pepper in Gangwon Province of South Korea, was reidentified as $C$. scovillei using combined sequence analyses of multiple genes. As a prerequisite for understanding the pathogenic development of the pepper anthracnose pathogen, we optimized the transformation system of $C$. scovillei KC05. Protoplast generation from young hyphae of $\mathrm{KC} 05$ was optimal in an enzymatic digestion using a combined treatment of $2 \%$ lysing enzyme and $0.8 \%$ driselase in 1 $\mathrm{M} \mathrm{NH} \mathrm{NH}_{4} \mathrm{Cl}$ for $3 \mathrm{~h}$ incubation. Prolonged incubation for more than $3 \mathrm{~h}$ decreased protoplast yields. Protoplast growth of $\mathrm{KC05}$ was completely inhibited for 4 days on regeneration media containing $200 \mu \mathrm{g} / \mathrm{ml}$ hygromycin

\footnotetext{
*Corresponding author.

Phone) +82-33-250-6435, FAX) +82-33-259-5558

E-mail)kims@kangwon.ac.kr

ORCID

Jong-Hwan Shin

https://orcid.org/0000-0002-6043-2775

Joon-Hee Han

https://orcid.org/0000-0001-8247-0943

Hyun-Hoo Park

https://orcid.org/0000-0002-7626-8658

Teng Fu

https://orcid.org/0000-0003-1310-6501

Kyoung Su Kim

https://orcid.org/0000-0002-0827-0844

(c) This is an Open Access article distributed under the terms of the Creative Commons Attribution Non-Commercial License (http:// creativecommons.org/licenses/by-nc/4.0) which permits unrestricted noncommercial use, distribution, and reproduction in any medium, provided the original work is properly cited.
}

Articles can be freely viewed online at www.ppjonline.org.
$B$, indicating the viability of this antibiotic as a selection marker. To evaluate transformation efficiency, we tested polyethylene glycol-mediated protoplast transformation of KC05 using 19 different loci found throughout 10 (of 27) scaffolds, covering approximately $84.1 \%$ of the entire genome. PCR screening showed that the average transformation efficiency was about $17.1 \%$ per 100 colonies. Southern blot analyses revealed that at least one transformant per locus had single copy integration of PCR-screened positive transformants. Our results provide valuable information for a functional genomics approach to the pepper anthracnose pathogen $C$. scovillei.

Keywords : Colletotrichum scovillei, pepper anthracnose, protoplast, transformation

Handling Editor : Jeon, Junhyun

Pepper (Capsicum annuum L.) belongs to the genus Capsicum in the Solanaceae family and is considered an economically important and popular vegetable crop. There are five domesticated species of peppers: $C$. annuum L., $C$. frutescens L., C. chinense Jacq., C. pubescens Ruiz \& Pav., and $C$. baccatum L. (Kraft et al., 2014). Among these, $C$. annuum is the most common and widely cultivated species worldwide (Oo et al., 2017, Saxena et al., 2016). In Korea, pepper is one of the most popular vegetables; approximately 72 thousand tons of peppers were produced in Korea in 2018, an increase of 16 thousand tons (28.4\%) from 56 thousand tons in 2017 (KOSTAT, Statistics Korea, http:// kostat.go.kr/portal/eng/). Pepper is valued for its beneficial effects on human wellness; it contains organic micronutrients, including carotenoids, flavonoids, and vitamins A, C, 
and $\mathrm{K}$, and this vegetable helps to reduce blood pressure and cholesterol levels (Dias, 2012). In addition to its health benefits, pepper is used fresh, as a spice, or as a minor ingredient in various dishes such as hot soup and kimchi.

Many fungal pathogens are known to cause diseases in pepper, including Colletotrichum species, which cause anthracnose disease; Rhizoctonia solani, which causes rhizoctonia root rot; and Phytophthora capsici and P. nicotianae, which cause phytophthora blight (Chi et al., 2013; Mannai et al., 2018; Than et al., 2008). Among these diseases, anthracnose is the most devastating fungal disease of pepper worldwide; yield losses of pepper are estimated at more than \$100 million USD in Korea (Oo et al., 2017; Than et al., 2008). The genus Colletotrichum contains approximately 189 species. Of these, 34 species are recognized within the $C$. acutatum species complex (Baroncelli et al., 2017). Many Colletotrichum species, including $C$. acutatum, C. gloeosporioides, and C. capsici, infect pepper (Bailey and Jeger, 1992; Than et al., 2008). Colletotrichum acutatum is one of the most frequently reported species causing anthracnose disease on pepper in tropical and subtropical countries (Han et al., 2016). Using combined sequence analyses of the $\beta$-tublin-2 (TUB2) gene, the glyceraldehyde-3-phosphate dehydrogenase (GAPDH) gene, and internal transcribed spacer (ITS) rDNA regions, $C$. scovillei (a member of the C. acutatum species complex) was recently shown to cause anthracnose disease on pepper in several countries including Brazil, China, Japan, and South Korea (Caires et al., 2014; Diao et al., 2017; Kanto et al., 2014; Zhao et al., 2016).

Fungal transformation can be a powerful tool in functional genomics (Fincham, 1989; Hynes, 1996). This technique enables researchers to understand the complex mechanisms of fungal infection and fungal pathogenesis at the molecular level. Most fungal transformation methods include the formation of fungal protoplasts that have had their cell walls removed using mechanical or enzymatic methods (Hayat and Christias, 2010; Song et al., 2015). Several factors influence the efficiency of protoplast generation, including fungal strain, culture media, culture temperature, culture $\mathrm{pH}$, age of mycelia, enzyme concentrations, enzyme types, and osmatic stabilizers (Chadegani et al., 1989; Eyini et al., 2006). Cellulase, 1,3-glucanase, chitinase, Trichoderma harzianum lysing enzyme, and driselase are frequently used as cell wall degrading enzymes (Hayat and Christias, 2010; Song et al., 2015; Xiao et al., 2013).

The factors affecting protoplast regeneration and transformation efficiency include type of antibiotics, vector size, form of DNA (PCR-amplified DNA, pre-linearized plasmid, or circular form plasmid), concentration of DNA, and method of transformation. Genetic transformation can be conducted using different transformation methods, including electroporation, Agrobacterium-mediated transformation, polyethylene glycol (PEG)-mediated transformation, and the Cas9 ribonucleoprotein gene editing system (Chung et al., 2002; Liu and Friesen, 2012; Moradi et al., 2013; Wang et al., 2018b). Among these, PEG-mediated transformation is a particularly simple and efficient method. In this study, we developed a transformation system of $C$. scovillei $\mathrm{KC} 05$ by optimizing the factors affecting protoplast generation, transformation, and regeneration. Our results will provide valuable tools for research of the molecular mechanisms of the pepper pathogen C. scovillei $\mathrm{KC} 05$.

\section{Materials and Methods}

Fungal strain identification. Colletotrichum acutatum $\mathrm{KC} 05$ isolated from an infected pepper fruit in Gangwon Province of South Korea was used in this study (Han et al., 2016). The isolate was identified based on combined sequence analyses of the nuclear ribosomal internal transcribed (ITS) region, $\beta$-tubulin (TUB2), actin (ACT), partial sequences of the chitin synthase 1 (CHS-1), an intron sequence of the glyceraldehyde-3-phosphate dehydrogenase (GAPDH), and histone 3 (HIS3) genes (Damm et al., 2012; da Silva et al., 2017). The six gene sequences of $C$. acutatum KC05 were obtained from Han et al. (2016), and the gene sequences of other Colletotrichum species $(C$. acutatum, $C$. scovillei, and $C$. simmondsii) were obtained from GenBank (Supplementary Table 1). Percentage sequence identities of the six genes were obtained from the National Center for Biotechnology Information database (NCBI) using nucleotide BLAST. A phylogenetic tree was generated using maximum likelihood analyses based on combined analyses of the six gene sequences of the selected Colletotrichum species.

Colletotrichum scovillei KC05 protoplast generation. Fungal conidia for protoplast generation were collected from a 10-day-old oatmeal medium agar (5\% oatmeal and $2.5 \%$ agar) culture, inoculated into $100 \mathrm{ml}$ complete medium broth $(0.6 \%$ yeast extract, $0.6 \%$ casamino acids, and $1 \%$ sucrose), and cultured on a shaker at $150 \mathrm{rpm}$ for 1 day at $25^{\circ} \mathrm{C}$ in the dark. The resultant mycelia were harvested onto a sterilized cheese cloth and washed twice with $20 \%$ sucrose. Lysing enzyme and driselase were suspended in 1 $\mathrm{M} \mathrm{NH}_{4} \mathrm{Cl}$ and sterilized through $20 \mu \mathrm{m}$ pore filters (Sigma, St. Louis, MO, USA). To evaluate the enzymatic effects for protoplast generation, the washed mycelia were divided into $1,500 \mathrm{mg}$ aliquots in $50 \mathrm{ml}$ conical centrifuge tubes 
(SPL, Pocheon, Korea) and resuspended with $10 \mathrm{ml} 1 \mathrm{M}$ $\mathrm{NH}_{4} \mathrm{Cl}$ containing different lytic enzymes. Then the suspension was incubated at $25^{\circ} \mathrm{C}$ with gentle shaking at 70 rpm, and protoplasts were counted using a hemocytometer. Protoplasts were pelleted by centrifugation at 5,000 rpm, washed, and suspended individually in $1.5 \mathrm{ml}$ microcentrifuge tubes containing $200 \mu \mathrm{l} 1 \times$ STC buffer $(40 \%$ sucrose, $1 \mathrm{M}$ Tris- $\mathrm{HCl}$, and $\left.1 \mathrm{M} \mathrm{CaCl}_{2}\right)$. A differential interference contrast microscope (Axio Imager.A2, Zeiss, Jena, Germany) was used to examine the shapes of protoplasts. Protoplasts were stored at $-75^{\circ} \mathrm{C}$. Experiments were conducted in triplicate and repeated three times. All data were processed using the SigmaStar statistical software package (SPSS Science, Chicago, IL, USA), and error bars represent $95 \%$ confidence intervals.

Sensitivity of $C$. scovillei KC05 protoplasts to antibiotics. Hygromycin B (Millipore, Billerica, MA, USA) and geneticin (Gibco Life Technologies, Carlsbad, CA, USA) were used as selection antibiotics. Aliquots $(200 \mu \mathrm{l})$ of protoplast suspension were transferred to $15 \mathrm{ml}$ conical centrifuge tubes, mixed with an equal volume of PTC buffer $(2 \times$ STC plus $40 \%$ PEG), incubated for $20 \mathrm{~min}$ at room temperature, and gently shaken in a rotary shaker for $5 \mathrm{~h}$. Different concentrations of antibiotics and incubated protoplast aliquots were added to regeneration media $(20 \%$ sucrose, $0.3 \%$ yeast extract, $0.3 \%$ casamino acids, $1 \%$ glucose, and $0.8 \%$ agar; autoclaved and cooled to $55^{\circ} \mathrm{C}$ ) and poured into Petri dishes ( $90 \mathrm{~mm}$ in diameter). Plates were incubated at $25^{\circ} \mathrm{C}$ in the dark for 4 days.
Protoplast transformation. Nineteen loci were selected from 10 of 27 different scaffolds (Han et al., 2016). For double-joint PCR and Southern blots, genomic DNA was extracted using a quick DNA extraction method (Chi et al., 2009). Gene knock-out constructs were generated using double-joint PCR (Park et al., 2014). Primer sequences used in this study are listed in Supplementary Table 2. The hygromycin phosphotransferase gene (HPH) cassette was amplified using the primers HPH_F (5'-GGCTTGGCTGGAGCTAGTGGAGG-3') and HPH_R (5'-CTCCGGAGCTGACATCGACACCAAC-3') from pBCATPH (Kim et al., 2009), and approximately $1.4 \mathrm{~kb}$ of two flanking regions of target loci were amplified using the primers $5 \mathrm{~F} / \mathrm{R}$ and $3 \mathrm{~F} / \mathrm{R}$. The two fragments of flanking regions and the HPH cassette were fused using double-joint PCR, and the final construct was amplified using the primers NF and NR. Five micrograms of the construct haboring hygromycin resistance gene cassettes were introduced into $200 \mu \mathrm{l} C$. scovillei $\mathrm{KC} 05$ protoplasts $\left(1 \times 10^{7}\right.$ protoplasts $\left./ \mathrm{ml}\right)$ using PEG-mediated transformation (Park et al., 2014; Sweigard et al., 1992). Transformed protoplasts and hygromycin B $(200 \mu \mathrm{g} / \mathrm{ml})$ were mixed with $100-\mathrm{ml}$ regeneration media (autoclaved and cooled to $55^{\circ} \mathrm{C}$ ) and poured into $90-\mathrm{mm}$ Petri dishes. The number of colonies growing on the regeneration media was counted 4 days after transformation, and PCR screening was performed using the primers SF/SR. Southern blot was performed according to standard procedures to determine the number of copies of the transformed construct (Shin et al., 2014).

Table 1. Percentage sequence identities of ITS, TUB3, ACT, CHS-1, GAPDH, and HIS3 genes from Colletotrichum species

\begin{tabular}{lrrrrrr}
\hline & \multicolumn{7}{c}{ \% Identity $^{\mathrm{a}}$} \\
\cline { 2 - 7 } & ITS $^{\mathrm{b}}$ & TUB2 & ACT & CHS-1 & GAPDH & HIS3 \\
\hline C. acutatum sensu lato & 100 & 100 & 100 & 100 & 100 & 100 \\
C. scovillei KC05 & 100 & 100 & 100 & 99 & 100 & 100 \\
C. scovillei CBS 126529 & 98 & 97 & 98 & 97 & 93 & 95 \\
C. simmondsii CBS 122122 & 95 & 96 & 94 & 96 & - & 94 \\
C. fioriniae CBS 128517 & 98 & 98 & 92 & 95 & 92 & 97 \\
C. acutatum CBS 112996 & & & & & & 89 \\
The other species in Colletotrichum genus & 87 & 89 & 83 & 90 & - & 90 \\
C. graminicola CBS 130826 & 85 & 84 & 80 & 88 & - & - \\
C. higginsianum IMI 349063 & 83 & 82 & 77 & - & - & 86 \\
C. gloeosporioides CBS 112999 & 80 & 81 & 78 & - & - & \\
C. orbiculare 104-T &
\end{tabular}

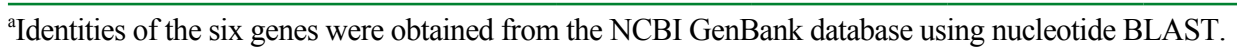

${ }^{b}$ ITS, internal transcribed spacer; TUB2, $\beta$-tubulin; ACT, actin; CHS-1, chitin synthase 1; GAPDH, glyceraldehyde-3-phosphate dehydrogenase; HIS3, histone 3. 


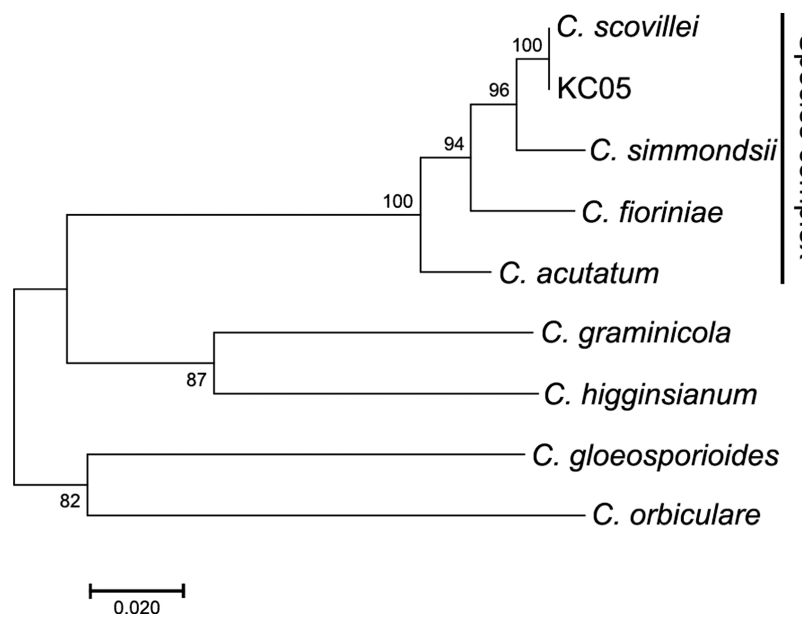

Fig. 1. Combined internal transcribed spacer (ITS), $\beta$-tubulin (TUB2), actin (ACT), chitin synthesis 1 (CHS-1), glyceraldehyde-3-phosphate dehydrogenase (GAPDH), and histone 3 (HIS3) gene sequences. The phylogenetic tree illustrates relationships among Colletotrichum species in C. scovillei $\mathrm{KC} 05$ isolated from Korean pepper. Numbers at nodes represent the percentages of occurrence in 1,000 bootstrap replicates. Scale bar indicates the number of nucleotide substitutions.

\section{Results}

Fungal strain identification. Colletotrichum acutatum is a species complex with many members (Baroncelli et al., 2017). The previously identified strain C. acutatum KC05 (Han et al., 2016) was used in the present study to confirm the identity in C. acutatum sensu lato. Gene sequences of ITS, TUB2, ACT, CHS-1, GAPDH, and HIS3, which are mainly used in species classification (Caires et al., 2014), were analyzed in C. acutatum KC05, for comparison with those in C. scovillei CBS 126529, C. simmondsii CBS 122122, C. fioriniae CBS 128517, C. acutatum CBS 112996, C. graminicola CBS 112999, C. higginsianum IMI 349063, C. gloeosporioides CBS 112999, and C. orbiculare CBS 104-T. This analysis revealed that the ITS, TUB2, ACT, GAPDH, and HIS3 gene sequences of $C$. scovillei $\mathrm{KC} 05$ had $100 \%$ identity matches with C. scovillei CBS 126529, and the CHS-1 sequence exhibited 99\% identity matches (Table 1). In the five multigene analyses, C. scovillei $\mathrm{KC} 05$ showed a higher match (>90\% identity) with members in C. acutatum sensu lato, C. scovillei, C. simmondsii, C. fioriniae, and C. acutatum, compared to the other species, $C$. graminicola, $C$. higginsianum, $C$. gloeosporioides, and C. orbiculare. A phylogenetic tree was subsequently constructed using the multigene sequences to analyze the genetic relationship among species.
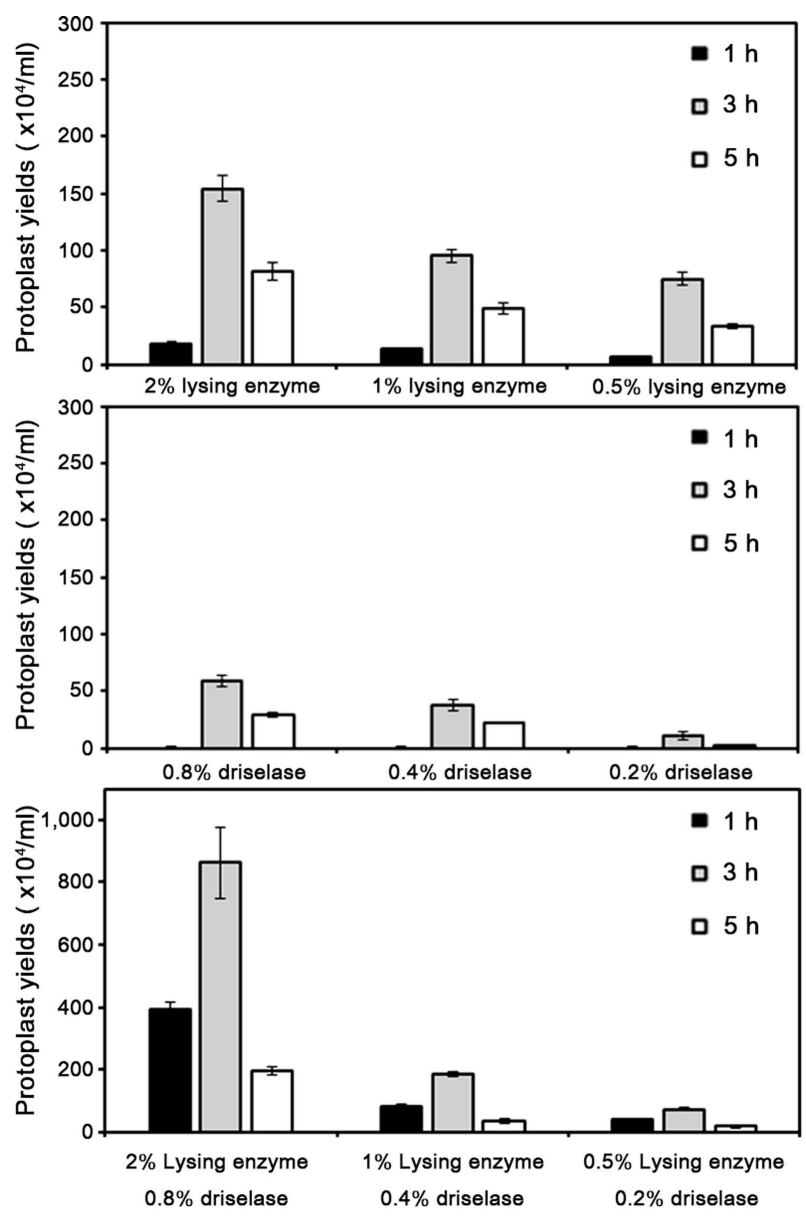

Fig. 2. Effect of different concentrations of lysing enzyme or driselase on protoplast yields of Colletotrichum scovillei $\mathrm{KC} 05$. Washed mycelia were divided into $1,500 \mathrm{mg}$ aliquots in $50 \mathrm{ml}$ conical centrifuge tubes, resuspended with $10 \mathrm{ml} 1 \mathrm{M} \mathrm{NH}_{4} \mathrm{Cl}$ containing different lytic enzymes, and incubated at $25^{\circ} \mathrm{C}$ with gentle shaking at $70 \mathrm{rpm}$. Experiments were conducted in triplicate and repeated three times. Error bars indicate standard deviations.

As expected, C. scovillei $\mathrm{KC} 05$ was grouped in a clade with the members of $C$. acutatum sensu lato, C. scovillei, C. simmondsii, C. fioriniae, and C. acutatum, in which $C$. scovillei $\mathrm{KC} 05$ was almost identical to the reference strain C. scovillei CBS 126529 (Fig. 1). This result is consistent with that of Oo et al. (2017) and further indicates that $C$. acutatum $\mathrm{KC} 05$ is C. scovillei.

Colletotrichum scovillei KC05 protoplast generation. As a step toward understanding pepper anthracnose disease, we optimized a transformation system of C. scovillei $\mathrm{KC} 05$. For protoplast generation of C. scovillei $\mathrm{KC05}$, two commonly available enzymes, lysing enzyme and driselase, were tested on C. scovillei KC05 mycelia. At $1 \mathrm{~h}$ after incubation of $C$. scovillei $\mathrm{KC} 05$ mycelia with lysing 

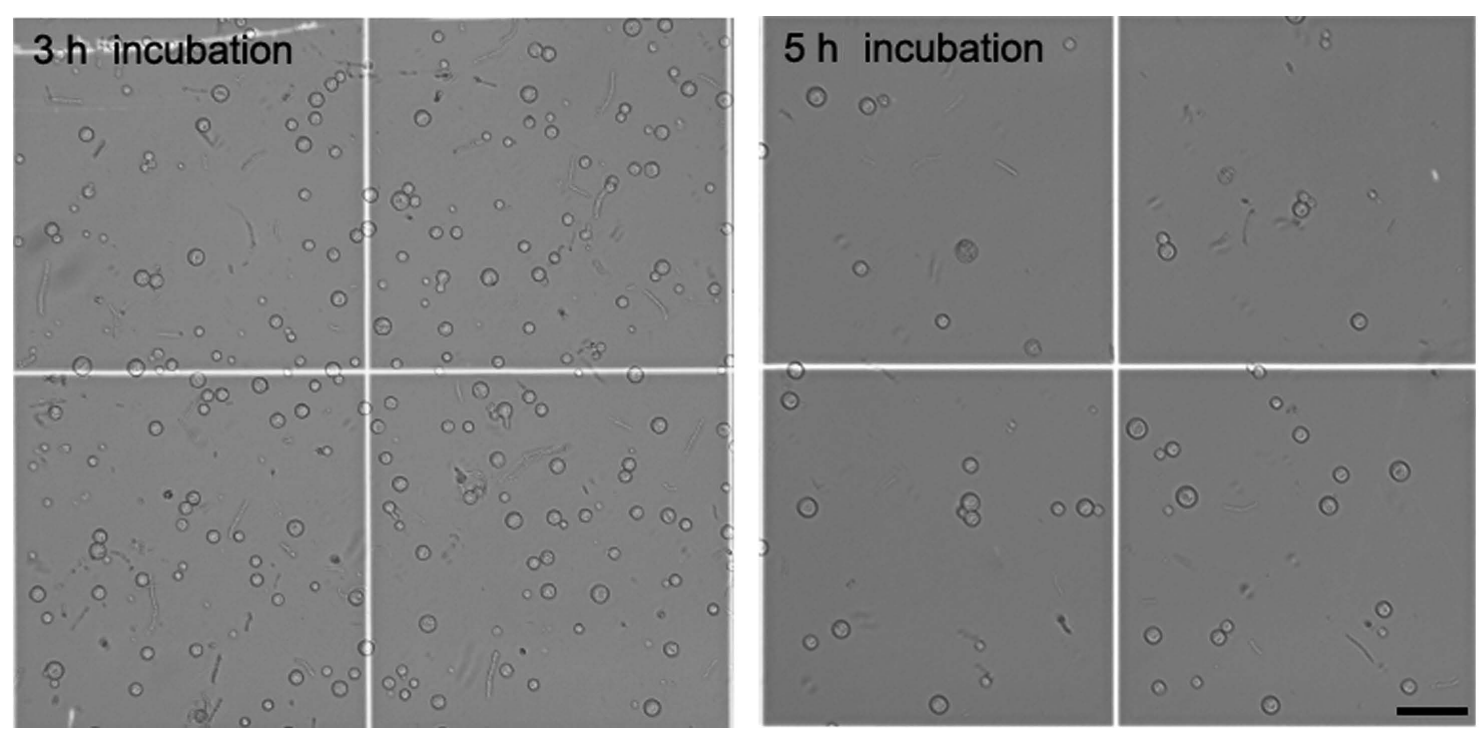

Fig. 3. The shape of released protoplasts of Colletotrichum scovillei KC05. The average size of protoplasts was $8.82 \pm 0.06 \mu \mathrm{m}$ after 3 $\mathrm{h}$ incubation and $11.09 \pm 0.07 \mu \mathrm{m}$ after $5 \mathrm{~h}$ incubation in the $2 \%$ lysing enzyme and $0.8 \%$ driselase mixture. Lysed protoplasts were observed after $5 \mathrm{~h}$ incubation under a differential interference contrast microscope. Scale bar $=50 \mu \mathrm{m}$.

enzyme, $6.0 \times 10^{4}$ protoplasts $/ \mathrm{ml}$ were released with $0.5 \%$ lysing enzyme (Fig. 2). The addition of more enzyme enhanced protoplast yields. Averages of $13.0 \times 10^{4}$ and 17.6 $\times 10^{4}$ protoplasts $/ \mathrm{ml}$ were released from C. scovillei $\mathrm{KC} 05$ mycelia with $1 \%$ and $2 \%$ lysing enzyme, respectively. Longer incubation times also enhanced protoplast yields. At $3 \mathrm{~h}$ after incubation with $0.5 \%$ lysing enzyme, $75 \times 10^{4}$ protoplasts $/ \mathrm{ml}$ were released, which was 12.5 -fold higher than after $1 \mathrm{~h}$ incubation. However, prolonged incubation for more than $3 \mathrm{~h}$ resulted in protoplast cell lysis; only 33.3 $\times 10^{4}$ protoplasts $/ \mathrm{ml}$ were released from mycelia at $5 \mathrm{~h}$ after incubation, which was approximately 2.2-fold lower than at $3 \mathrm{~h}$ incubation. Driselase released lower numbers of protoplasts compared to lysing enzyme. The maximum release of protoplasts with driselase was obtained with $0.8 \%$ driselase at $3 \mathrm{~h}$ incubation, which released approximately $58 \times 10^{4}$ protoplasts $/ \mathrm{ml}$. A combination of the two enzymes released more protoplasts than just one enzyme alone; $2 \%$ lysing enzyme and $0.8 \%$ driselase with $3 \mathrm{~h}$ incubation produced the maximum release of protoplasts, $860 \times 10^{4}$ protoplasts $/ \mathrm{ml}$.

The shapes of released protoplasts were spherical, and their average size was $8.82 \pm 0.06 \mu \mathrm{m}$ in diameter after 3 $\mathrm{h}$ incubation in the $2 \%$ lysing enzyme and $0.8 \%$ driselase mixture (Fig. 3). After $5 \mathrm{~h}$ incubation in the same mixture, the average size of protoplasts was $11.09 \pm 0.07 \mu \mathrm{m}$, much larger than at $3 \mathrm{~h}$ incubation. Noticeably, lysed protoplasts were observed after $5 \mathrm{~h}$ incubation. These results indicate that the combination of lysing enzyme and driselase at $3 \mathrm{~h}$

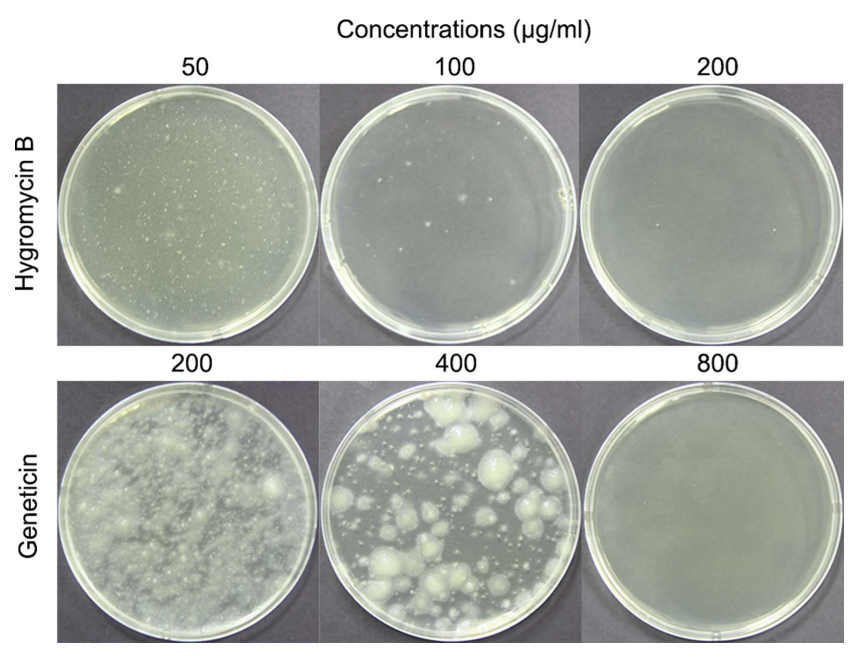

Fig. 4. Sensitivity of Colletotrichum scovillei $\mathrm{KC0} 05$ protoplasts to antibiotics. Hygromycin B and geneticin were used as selection antibiotics. Different concentrations of antibiotics and protoplasts were added to regeneration media and poured into $90-\mathrm{mm}$ Petri dishes. Plates were incubated at $25^{\circ} \mathrm{C}$ in the dark for 4 days.

incubation is most effective for protoplast generation from mycelia of C. scovillei.

Sensitivity of $C$. scovillei KC05 protoplasts to antibiotics. The sensitivity of $C$. scovillei $\mathrm{KC} 05$ protoplasts to antibiotics was assessed to select a positive transformation marker and to determine the minimal concentration of antibiotics required. Hygromycin B and geneticin were used as the selective antibiotics, as both have been widely used for 


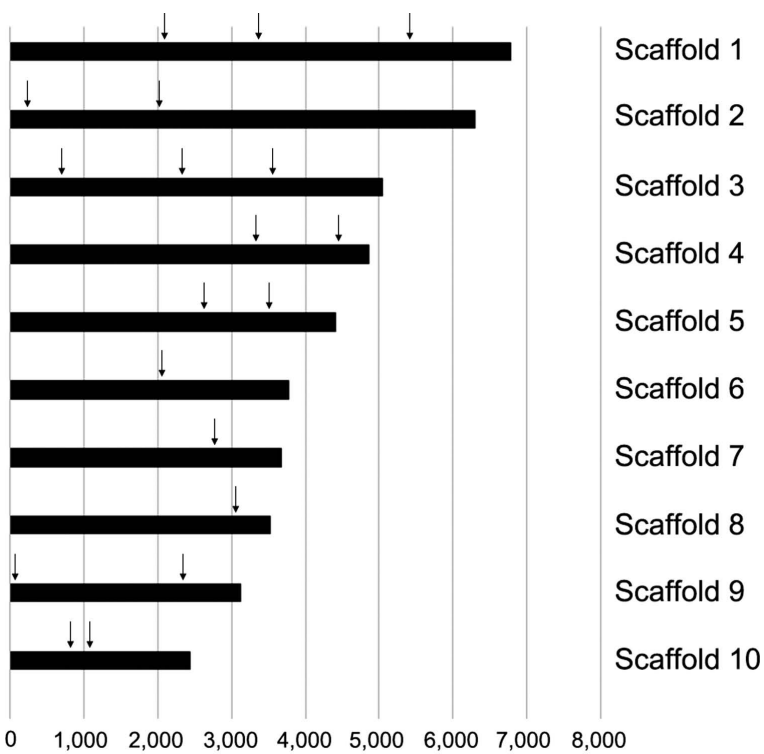

Genome sequence length $(\mathrm{kb})$

Fig. 5. Distribution of 19 loci in 10 scaffolds of Colletotrichum scovillei KC05. Scaffold 1 (annotation numbers: CSP_000583, CSP_000836, and CSP_001376; scaffold 2 (CSP_001741 and CSP_002212); scaffold 3 (CSP_003491, CSP 003850, and CSP 004175); scaffold 4 (CSP 005482 and CSP_005764); scaffold 5 (CSP_006607 and CSP_006807); scaffold 6 (CSP_007586); scaffold 7 (CSP_008738); scaffold 8 (CSP_009802); scaffold 9 (CSP_010617 and CSP_009947); and scaffold 10 (CSP_010985 and CSP_011033). Each locus is ordered from left to right in each scaffold bar. fungal transformation. Results indicated that hygromycin B completely inhibited the growth of $C$. scovillei $\mathrm{KC} 05$ protoplasts at a concentration of $200 \mu \mathrm{g} / \mathrm{ml}$ (Fig. 4). However, at lower concentrations (50 and $100 \mu \mathrm{g} / \mathrm{ml}$ ), protoplast growth was not completely inhibited. Compared to hygromycin $\mathrm{B}$, protoplasts were more resistant to geneticin; protoplast growth was not completely inhibited at concentrations of either 200 or $400 \mu \mathrm{g} / \mathrm{ml}$. However, $800 \mu \mathrm{g} / \mathrm{ml}$ geneticin was able to completely inhibit protoplast growth. Based on these results, different concentrations of the two antibiotics were used in the selection of transformants of $C$. scovillei $\mathrm{KC} 05$.

Protoplast transformation. To better understand the transformation efficiency of C. scovillei KC05, a total of 19 loci were randomly selected from the $\mathrm{KC} 05$ genome (Han et al., 2016). These loci were scattered throughout 10 (out of 27) different scaffolds, which covered $49.9 \mathrm{Mb}$, equivalent to $84.1 \%$ of the whole genome (Fig. 5). For the homology-dependent replacement of a targeted gene, knock-out DNA constructs were generated for the 19 loci using PCR. Protoplasts of KC05 were transformed with DNA of each knock-out construct (Figs. 5 and 6A). Transformed protoplasts were grown on regenaration media in $90-\mathrm{mm}$ Petri dishes supplemented with hygromycin B. Many transformants were regenerated at 4 days after transformation, and 45-138 transformants were subsequently selected to simply screen putative knock-out transformants using a PCR
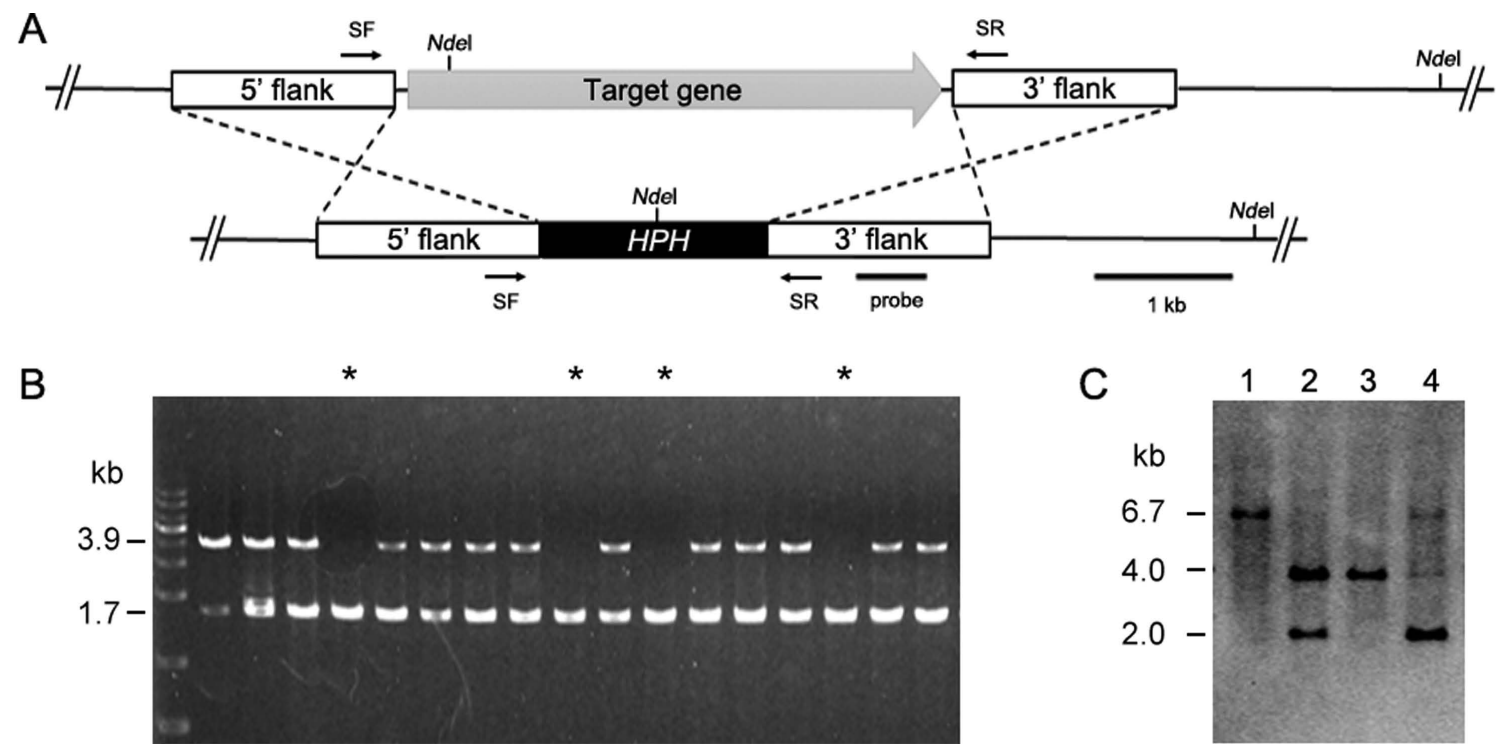

Fig. 6. Construction of a gene knock-out system and identification of deletion mutant. (A) CSP_006607 gene (gray arrow) was deleted through the targeted gene replacement method. (B) PCR screening was performed using the primers SF/SR. The primer pair produced a 1.7-kb band from gene knock-out transformants (indicated by an asterisk) and both 1.7- and 3.9-kb bands from random insertional transformants. (C) Southern blot analyses. DNA samples were digested with NdeI. A 6.7-kb band was produced from wild type KC05, and a 4.0-kb band was produced from a knock-out mutant. Lane 1, wild type; lane 2, ectopic; lane 3, knock-out mutant; and lane 4, ectopic. 
Table 2. Summary of transformation efficiencies and generation of knock-out mutants for the 19 loci in Colletotrichum scovillei strain $\mathrm{KC} 05$

\begin{tabular}{|c|c|c|c|c|c|}
\hline $\begin{array}{l}\text { Target } \\
\text { locus }\end{array}$ & $\begin{array}{l}\text { Size of target locus for } \\
\text { homology-dependent } \\
\text { replacement (bp) }\end{array}$ & $\begin{array}{c}\text { No. of transformants } \\
\text { tested for PCR } \\
\text { screening }\end{array}$ & $\begin{array}{c}\text { No. of positive } \\
\text { candidates for } \\
\text { knock-out mutants in } \\
\text { PCR screening }\end{array}$ & $\begin{array}{l}\text { Percentage of } \\
\text { positive candidates in } \\
\text { PCR screening }\end{array}$ & $\begin{array}{l}\text { No. of knock-out } \\
\text { mutants confirmed in } \\
\text { Southern blots }\end{array}$ \\
\hline CSP_000836 & 2,413 & 95 & 15 & 15.7 & $2 / 3$ \\
\hline CSP_001376 & 2,685 & 114 & 15 & 13.1 & $2 / 3$ \\
\hline CSP_000583 & 2,262 & 118 & 18 & 15.2 & $2 / 2$ \\
\hline CSP_001741 & 2,727 & 103 & 12 & 11.6 & $2 / 3$ \\
\hline CSP_002212 & 638 & 138 & 20 & 14.4 & $3 / 3$ \\
\hline CSP_004175 & 1,982 & 109 & 19 & 17.4 & $3 / 3$ \\
\hline CSP_003850 & 2,295 & 121 & 21 & 17.3 & $3 / 3$ \\
\hline CSP_003491 & 585 & 119 & 26 & 21.8 & $1 / 5$ \\
\hline CSP_005482 & 1,407 & 88 & 17 & 19.3 & $2 / 3$ \\
\hline CSP_005764 & 3,789 & 113 & 17 & 15.0 & $2 / 2$ \\
\hline CSP_006569 & 1,883 & 111 & 8 & 7.2 & $3 / 3$ \\
\hline CSP_006607 & 556 & 106 & 25 & 23.5 & $3 / 5$ \\
\hline CSP_007586 & 678 & 45 & 5 & 11.1 & $5 / 5$ \\
\hline CSP_008738 & 970 & 81 & 12 & 14.8 & $2 / 4$ \\
\hline CSP_009802 & 496 & 111 & 18 & 16.2 & $2 / 5$ \\
\hline CSP_010617 & 3,976 & 93 & 26 & 27.9 & $3 / 3$ \\
\hline CSP_009947 & 303 & 108 & 18 & 16.6 & $1 / 2$ \\
\hline CSP_010985 & 2,028 & 81 & 24 & 29.6 & $3 / 3$ \\
\hline CSP_011033 & 1,260 & 113 & 21 & 18.5 & $2 / 2$ \\
\hline
\end{tabular}

method (Table 2). The PCR screening was performed with the primers SF/SR using genomic DNA extracted from the transformants (Fig. 6B). Two bands at 1.7 and $3.9 \mathrm{~kb}$ were amplified within many transformants (Fig. 6B), as illustrated in Fig. 6A. These results suggest that the targeted gene remained intact and that the DNA constructs were ectopically integrated in the genome. However, the detection of only the $1.7 \mathrm{~kb}$ band in several transformants suggests possible knock-out candidates via a homology-dependent replacement event. By measuring one band in transformants for the 19 loci, we obtained a variable number of positive candidates, ranging from 5 to 26 (Table 2). For example, 24 of 81 transformants were positively detected as knock-out candidates for the CSP_010985 locus, while 8 of 111 transformants were positive in the PCR screening for CSP_006969. The average number of candidates for knock-out mutants was $17.1 \%$ for the 19 loci tested in the PCR screening. To confirm the target gene-specific replacement in knock-out transformants, Southern blot analyses were performed with transformants. As illustrated in Fig. 6A, genomic DNA of transformants was digested using NdeI and then hybridized with the indicated probe. The analyses revealed that $4.0 \mathrm{~kb} \mathrm{NdeI}$ bands were only detected in knock-out mutants, while 6.7 and $2 \mathrm{~kb}$ bands originated from transformants with ectopic integration and the wild-type copy of the gene, respectively (Fig. 6C). Knock-out mutants were obtained for different sizes of the 19 targeted loci (Table 2).

\section{Discussion}

C. acutatum is an important anthracnose pathogen commonly identified from a wide range of host plants. Several studies have recently identified subgroups within the $C$. acutatum species complex, using the combined gene sequences of ITS, TUB2, ACT, CHS-1, GAPDH, and HIS3 (Bragança et al., 2016; Damm et al., 2012). For example, C. scovillei is proven to be separate species of the C. acutatum species complex through multigene sequence analysis (Damm et al., 2012). Within the C. acutatum species complex, C. scovillei has frequently been identified as a causal agent, most frequently from fruit-rots including peppers. Supportively, Oo et al. (2017) collected 35 isolates of Colletotrichum sp. from infected pepper fruits in South Korea, and subsequently identified the isolates using the TUB2, GAPDH, and ITS sequences of strain CBS 126529. All of these isolates were identified as $C$. scovillei. In the present study, C. acutatum $\mathrm{KC} 05$ isolated from infected pepper 
fruits in South Korea was idenfied as $C$. scovillei using the ITS, TUB2, ACT, CHS-1, GAPDH, and HIS3 sequences. Based on our results and those of previous studies, we concluded that $C$. scovillei is an important anthracnose pathogen of pepper fruits in South Korea. In a previous study, we collected 30 Colletotrichum strains from pepper and apple fruits in several fields of Gangwon Province (data not shown). Through analyses of ITS sequences, we confirmed that the isolates were $C$. gloeosporioides, $C$. acutatum, $C$. graminicola, and C. fioriniae. In future studies, we plan to collect more Colletotrichum species from various fruits to then identify isolates using combined sequence analyses of the ITS, TUB2, ACT, CHS-1, GAPDH, and HIS3 genes.

The key factors affecting protoplast release of filamentous fungi include the type of enzymes, enzyme combinations, age of mycelia, and incubation time (da Silva Coelho et al., 2010; Xiao et al., 2013). Rehman et al. (2016) optimized the protoplast isolation, regeneration, and transformation efficiency of Verticillium dahlia, the causal agent of Verticillium wilt. The maximum release of protoplasts was obtained using $200 \mathrm{mg}$ driselase in $10 \mathrm{ml} \mathrm{NaCl}(0.7$ $\mathrm{M})$ at $2.5 \mathrm{~h}$ after incubation. Similar to our data, prolonged incubation times resulted in lysing of protoplasts. Cheng and Bélanger (2000) described a protocol for yielding protoplasts from Pseudozyma flocculosa, a powdery mildew biocontrol agent. In their experiment, $0.5 \%$ Novozyme 234 was the most efficient enzyme, followed by $5 \%$ Glucanex. The maximum release of protoplasts was obtained from a combination of $0.5 \%$ Novozyme 234 and $5 \%$ Glucanex (Cheng and Bélanger, 2000). Ramamoorthy et al. (2015) evaluated various cell wall degrading enzymes for the production of protoplasts in Fusarium verticillioides and concluded that a combination of lysing enzyme and driselase was effective for protoplast production. In the present study, we determined that the combination of $2 \%$ lysing enzyme and $0.8 \%$ driselase in $1 \mathrm{M} \mathrm{NH}_{4} \mathrm{Cl}$ with $3 \mathrm{~h}$ incubation was optimal for protoplast release in C. scovillei $\mathrm{KC} 05$. Consistent with these previous studies, prolonged incubation times resulted in the generation of fewer protoplasts, and the combination of different enzymes resulted in the release of more protoplasts than with one enzyme alone.

Prior to transformation, a suitable selection marker must be chosen for transformation. Hygromycin B is the most commonly used antibiotic as a selection marker for tranformation in Ascomycota (Yörük and Albayrak, 2015). Geneticin, on the other hand, is used for complement transformation (Han et al., 2015, Wang et al., 2018a). In the present study, we selected hygromycin B and geneticin as selective markers and evaluated their effectiveness for the growth inhibition of C. scovillei $\mathrm{KC} 05$ protoplasts. Chung et al. (2013) generated gene deletion mutants in Magnaporthe oryzae via selection on regeneration media supplemented with hygromycin B $(200 \mu \mathrm{g} / \mathrm{ml}$ concentration) or geneticin ( $800 \mu \mathrm{g} / \mathrm{ml}$ concentration). Talhinhas et al. (2008) developed a protocol for efficient Agrobacterium tumefaciensmediated transformation (ATMT) of $C$. acutatum. They used hygromycin $\mathrm{B}$ as a selective marker, and growth of $C$. acutatum isolate 397 was completely inhibited at $250 \mu \mathrm{g} /$ $\mathrm{ml}$ hygromycin B. Consistent with these results, $200 \mu \mathrm{g} / \mathrm{ml}$ hygromycin B media and $800 \mu \mathrm{g} / \mathrm{ml}$ geneticin media were the optimal concentrations for selecting C. acutatum $\mathrm{KC} 05$ transformants in the present study.

Fungal transformation is an essential technology in the study of fungal pathogenicity genes at the molecular level. Several fungal transformation technologies have been developed, and PEG-mediated transformation is a simple and inexpensive method (Mathur and Koncz, 1998). Transformation efficiency can vary depending on the technology used and the organism transformed. Armesto et al. (2012) obtained only 21 transformants from C. gloeosporioides (1 $\times 10^{7}$ protoplasts $/ \mathrm{ml}$ ) using PEG-mediated transformation, whereas Talhinhas et al. (2008) obtained 45-156 transformants of C. acutatum using the ATMT protocol. Among the 45-156 transformants, Southern blot analyses revealed that more than $70 \%$ contained single copy integration of TDNA (Talhinhas et al., 2008). Maruthachalam et al. (2008) also performed ATMT for two Colletotrichum species, and Southern blot analyses indicated that about $65 \%$ of $C$. acutatum and $62 \%$ of $C$. falcatum transformants contained single copy integration of T-DNA. In the present study, we obtained an average of 103 transformants from 19 different loci of C. scovillei KC05 using PEG-mediated transformation. Southern blot analyses using 2-5 gene knock-out transformants showed that at least one transformant had single copy integration. Moreover, we selected 19 loci from over 10 scaffolds that covered approximately $84.1 \%$ of the entire $52,190,760 \mathrm{bp}$ genome to perform a more distributed target gene knock-out (Han et al., 2016). Our results provide a valuable tool for high-throughput genetic analyses of C. scovillei.

\section{Acknowledgments}

This study was supported by Basic Science Research Program through the National Research Foundation of Korea grant (NRF-2017R1D1A1B03029622) funded by the Ministry of Education, Science and Technology, and by a grant (918019-04) from the Strategic Initiative for Microbiomes in Agriculture and Food, Ministry of Agriculture, Food and 
Rural Affairs, Republic of Korea.

\section{Electronic Supplementary Material}

Supplementary materials are available at The Plant Pathology Journal website (http://www.ppjonline.org/).

\section{References}

Armesto, C., Maia, F. G. M., de Abreu, M. S., Figueira, A. D. R., da Silva, B. M. and Monteiro, F. P. 2012. Genetic transformation with the $g f p$ gene of Colletotrichum gloeosporioides isolates from coffee with blister spot. Braz. J. Microbiol. 43:1222-1229.

Bailey, J. A. and Jeger, M. J. 1992. Colletotrichum: biology, pathology and control. C.A.B. International, Wallingford, UK. 388 pp.

Baroncelli, R., Talhinhas, P., Pensec, F., Sukno, S. A., Le Floch, G. and Thon, M. R. 2017. The Colletotrichum acutatum species complex as a model system to study evolution and host specialization in plant pathogens. Front. Microbiol. 8:2001.

Bragança, C. A. D., Damm, U., Baroncelli, R., Massola Júnior, N. S. and Crous, P. W. 2016. Species of the Colletotrichum acutatum complex associated with anthracnose diseases of fruit in Brazil. Fungal Biol. 120:547-561.

Caires, N. P., Pinho, D. B., Souza, J. S. C., Silva, M. A., Lisboa, D. O., Pereira, O. L. and Furtado, G. Q. 2014. First report of anthracnose on pepper fruit caused by Colletotrichum scovillei in Brazil. Plant Dis. 98:1437.

Chadegani, M., Brink, J. J., Shehata, A. and Ahmadjian, V. 1989. Optimization of protoplast formation, regeneration, and viability in Microsporum gypseum. Mycopathologia 107:33-50.

Cheng, Y. and Bélanger, R. R. 2000. Protoplast preparation and regeneration from spores of the biocontrol fungus Pseudozyma flocculosa. FEMS Microbiol. Lett. 190:287-291.

Chi, M.-H., Park, S.-Y. and Lee, Y.-H. 2009. A quick and safe method for fungal DNA extraction. Plant Pathol. J. 25:108111.

Chi, T. T. P., Choi, O., Kwak, Y.-S., Son, D., Lee, J. J. and Kim, J. 2013. Streptomyces padanus for the biological control of Phytophthora capsici on pepper plants. J. Agric. Life Sci. 47:1-9.

Chung, H., Choi, J., Park, S.-Y., Jeon, J. and Lee, Y.-H. 2013. Two conidiation-related $\mathrm{Zn}(\mathrm{II})_{2} \mathrm{Cys}_{6}$ transcription factor genes in the rice blast fungus. Fungal Genet. Biol. 61:133-141.

Chung, K.-R., Shilts, T., Li, W. and Timmer, L. W. 2002. Engineering a genetic transformation system for Colletotrichum acutatum, the causal fungus of lime anthracnose and postbloom fruit drop of citrus. FEMS Microbiol. Lett. 213:33-39.

Damm, U., Cannon, P. F., Woudenberg, J. H. C. and Crous, P. W. 2012. The Colletotrichum acutatum species complex. Stud. Mycol. 73:37-113.

da Silva Coelho, I., de Queiroz, M. V., Costa, M. D., Kasuya, M. C.
M. and de Araújo, E. F. 2010. Production and regeneration of protoplasts from orchid mycorrhizal fungi Epulorhiza repens and Ceratorhiza sp. Braz. Arch. Biol. Technol. 53:153-159.

de Silva, D. D., Ades, P. K., Crous, P. W. and Taylor, P. W. J. 2017. Colletotrichum species associated with chili anthracnose in Australia. Plant Pathol. 66:254-267.

Diao, Y.-Z., Zhang, C., Liu, F., Wang, W.-Z., Liu, L., Cai, L. and Liu, X.-L. 2017. Colletotrichum species causing anthracnose disease of chili in China. Persoonia 38:20-37.

Dias, J. S. 2012. Nutritional quality and health benefits of vegetables: a review. Food Nutr. Sci. 3:1354-1374.

Eyini, M., Rajkumar, K. and Balaji, P. 2006. Isolation, regeneration and PEG-induced fusion of protoplasts of Pleurotus pulmonarius and Pleurotus florida. Mycobiology 34:73-78.

Fincham, J. R. S. 1989. Transformation in fungi. Microbiol. Rev. 53:148-170.

Han, J.-H., Chon, J.-K., Ahn, J.-H., Choi, I.-Y., Lee, Y.-H. and Kim, K. S. 2016. Whole genome sequence and genome annotation of Colletotrichum acutatum, causal agent of anthracnose in pepper plants in South Korea. Genom. Data 8:45-46.

Han, J.-H., Lee, H.-M., Shin, J.-H., Lee, Y.-H. and Kim, K. S. 2015. Role of the MoYAK1 protein kinase gene in Magnaporthe oryzae development and pathogenicity. Environ. Microbiol. 17:4672-4689.

Hayat, S. and Christias, C. 2010. Isolation and fusion of protoplasts from the phytopathogenic fungus Sclerotium rolfsii (Sacc.). Braz. J. Microbiol. 41:253-263.

Hynes, M. J. 1996. Genetic transformation of filamentous fungi. $J$. Genet. 75:297-311.

Kanto, T., Uematsu, S., Tsukamoto, T., Moriwaki, J., Yamagishi, N., Usami, T. and Sato, T. 2014. Anthracnose of sweet pepper caused by Colletotrichum scovillei in Japan. J. Gen. Plant Pathol. 80:73-78.

Kim, S., Park, S.-Y., Kim, K. S., Rho, H.-S., Chi, M.-S., Choi, J., Park, J., Kong, S., Park, J., Goh, J. and Lee, Y.-H. 2009. Homeobox transcription factors are required for conidiation and appressorium development in the rice blast fungus Magnaporthe oryzae. PLoS Genet. 5:e1000757.

Kraft, K. H., Brown, C. H., Nabhan, G. P., Luedeling, E., Luna Ruize, J. D. J., d'Eeckenbrugge, G. C., Hijmans, R. J. and Gepts, P. 2014. Multiple lines of evidence for the origin of domesticated chili pepper, Capsicum annuum, in Mexico. Proc. Natl. Acad. Sci. U. S. A. 111:6165-6170.

Liu, Z. and Friesen, T. L. 2012. Polyethylene glycol (PEG)-mediated transformation in filamentous fungal pathogens. Methods Mol. Biol. 835:365-375.

Mannai, S., Jabnoun-Khiareddine, H., Nasraoui, B. and DaamiRemadi, M. 2018. Rhizoctonia root rot of pepper (Capsicum annuum): comparative pathogenicity of causal agent and biocontrol attempt using fungal and bacterial agents. J. Plant Pathol. Microbiol. 9:2.

Maruthachalam, K., Nair, V., Rho, H.-S., Choi, J., Kim, S. and Lee, Y.-H. 2008. Agrobacterium tumefaciens-mediated transformation in Colletotrichum falcatum and C. acutatum. J. 
Microbiol. Biotechnol. 18:234-241.

Mathur, J. and Koncz, C. 1998. PEG-mediated protoplast transformation with naked DNA. Methods Mol. Biol. 82:267-276.

Moradi, S., Sanjarian, F., Safaie, N., Mousavi, A. and Bakhshi Khaniki, G. R. 2013. A modified method for transformation of Fusarium graminearum. J. Crop Prot. 2:297-304.

Oo, M. M., Lim, G., Jang, H. A. and Oh, S.-K. 2017. Characterization and pathogenicity of new record of anthracnose on various chili varieties caused by Colletotrichum scovillei in Korea. Mycobiology 45:184-191.

Park, J., Kong, S., Kim, S., Kang, S. and Lee, Y.-H. 2014. Roles of forkhead-box transcription factors in controlling development, pathogenicity, and stress response in Magnaporthe oryzae. Plant Pathol. J. 30:136-150.

Ramamoorthy, V., Govindaraj, L., Dhanasekaran, M., Vetrivel, S., Kumar, K. K. and Ebenezar, E. 2015. Combination of driselase and lysing enzyme in one molar potassium chloride is effective for the production of protoplasts from germinated conidia of Fusarium verticillioides. J. Microbiol. Methods 111:127-134.

Rehman, L., Su, X., Guo, H., Qi, X. and Cheng, H. 2016. Protoplast transformation as a potential platform for exploring gene function in Verticillium dahliae. BMC Biotechnol. 16:57.

Saxena, A., Raghuwanshi, R., Gupta, V. K. and Singh, H. B. 2016. Chilli anthracnose: the epidemiology and management. Front. Microbiol. 7:1527.

Shin, J.-H., Han, J.-H. and Kim, K. S. 2014. Genome-wide analyses of DNA-binding proteins harboring AT-hook motifs and their functional roles in the rice blast pathogen, Magnaporthe oryzae. Genes Genomics 36:871-881.

Song, Z., Bakeer, W., Marshall, J. W., Yakasai, A. A., Khalid, R. M., Collemare, J., Skellam, E., Tharreau, D., Lebrun, M.-H., Lazarus, C. M., Bailey, A. M., Simpson, T. J. and Cox, R. J. 2015. Heterologous expression of the avirulence gene ACE1 from the fungal rice pathogen Magnaporthe oryzae. Chem. Sci. 6:4837-4845.

Sweigard, J. A., Chumley, F. G. and Valent, B. 1992. Disruption of a Magnaporthe grisea cutinase gene. Mol. Gen. Genet. 232:183-190.

Talhinhas, P., Muthumeenakshi, S., Neves-Martins, J., Oliveira, H. and Sreenivasaprasad, S. 2008. Agrobacterium-mediated transformation and insertional mutagenesis in Colletotrichum acutatum for investigating varied pathogenicity lifestyles. Mol. Biotechnol. 39:57-67.

Than, P. P., Prihastuti, H., Phoulivong, S., Taylor, P. W. J. and Hyde, K. D. 2008. Chilli anthracnose disease caused by Colletotrichum species. J. Zhejiang Univ. Sci. B 9:764-778.

Wang, Q., An, B., Hou, X., Guo, Y., Luo, H. and He, C. $2018 \mathrm{a}$. Dicer-like proteins regulate the growth, conidiation, and pathogenicity of Colletotrichum gloeosporioides from Hevea brasiliensis. Front. Microbiol. 8:2621.

Wang, Q., Cobine, P. A. and Coleman, J. J. 2018b. Efficient genome editing in Fusarium oxysporum based on CRISPR/ Cas9 ribonucleoprotein complexes. Fungal Genet. Biol. 117:21-29.

Xiao, S., Sun, Y., Tian, C. and Wang, Y. 2013. Optimization of factors affecting protoplast preparation and transformation of smoke-tree wilt fungus Verticillium dahliae. Afr. J. Microbiol. Res. 7:2712-2718.

Yörük, E. and Albayrak, G. 2015. Geneticin (G418) resistance and electroporation-mediated transformation of Fusarium graminearum and F. culmorum. Biotechnol. Equip. 29:268273.

Zhao, W., Wang, T., Chen, Q. Q., Chi, Y. K., Swe, T. M. and Qi, R. D. 2016. First report of Colletotrichum scovillei causing anthracnose fruit rot on pepper in Anhui Province, China. Plant Dis. 100:2168. 